\title{
MENGUJI EFEKTIFITAS SANKSI PIDANA UNTUK KASUS PENCEMARAN NAMA BAIK DALAM KEHIDUPAN NYATA DAN DUNIA MAYA
}

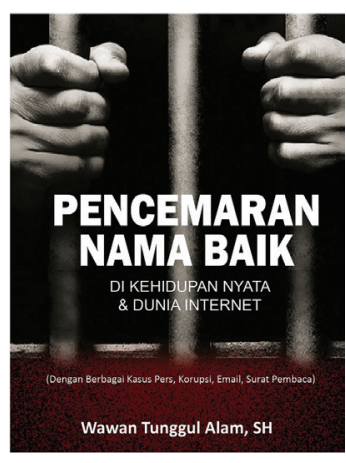

\section{Resensi}

Judul

Penyunting

Penulis

Penerbit

Jumlah

ISBN

Resensi
: Pencemaran Nama Baik di Kehidupan Nyata \& Dunia Internet

Fenomena merebaknya kasus pencemaran nama baik dan ujaran kebencian yang terjadi di Indonesia selalu menarik untuk diperbincangkan. Dengan kenyataan bahwa negara melalui pemerintahan yang sedang berkuasa saat ini sudah memberikan kebebasan berekspresi khususnya dalam hal mengutarakan pendapat kepada warganya, hal ini kerap menimbulkan masalah tersendiri. Dengan adanya kebebasan berpendapat itu, kemudian banyak orang melupakan batasanbatasan yang tidak boleh dilanggar, misalnya kaitannya dengan permasalahan hukum, etika, dan moral ketika seseorang berniat untuk mengungkapkan kritik atau pendapatnya di muka publik. Kemajuan teknologi yang semakin kencang, khususnya di Indonesia mendukung upaya pemerintah untuk membangun gaya demokratis dalam berbangsa dan bernegara. Dengan demikian masyarakat bisa dimudahkan untuk mengemukakan pendapatnya melalui media apapun, baik secara langsung maupun lewat beragam fitur media sosial yang sangat mudah dioperasikan oleh siapapun di dunia maya.

Keadaan ini tentu semakin memudahkan setiap manusia sebagai warga negara yang

*) Alumni Universitas Islam Indonesia Yogyakarta terkadang merasa tidak memiliki akses secara langsung untuk menyampaikan masukan atau kritik kepada birokrat maupun lembaga lainnya. Akan tetapi, dengan kondisi yang menunjukkan bahwa setiap orang secara bebas menyampaikan pendapatnya di muka umum, aparat sebagai penegak hukum justru kesulitan untuk melakukan kontrol terhadap masyarakat selaku subyek hukum. Padahal sudah ada berbagai macam undang-undang yang menjadi regulasi dan memuat ketentuan-ketentuan khusus terkait kebebasan berpendapat di dunia nyata maupun dunia maya ini. Seperti misalnya dalam KUHP (Kitab Undang-Undang Hukum Pidana) yang berlaku di Indonesia, ketentuan hukum mengenai pencemaran nama baik dapat ditemukan pada pasal 310-321 KUHP. Sedangkan khusus untuk pencemaran nama baik yang dilakukan melalui internet juga diatur dalam Undang-Undang Nomor 11 Tahun 2008 tentang Informasi dan Transaksi Elektronik atau yang selanjutnya disebut dengan UU ITE.

Berawal dari kegundahan karena diterobosnya norma-norma hukum serta adat kesopanan dalam mengemukakan pendapat di muka publik, baik melalui kehidupan nyata maupun dunia internet, buku Pencemaran Nama Baik di Kehidupan Nyata dan Dunia 
Internet menarik untuk menjadi bahan diskusi di tengah merebaknya kasus pencemaran nama baik dan ujaran kebencian yang ada di Indonesia. Bagian pertama buku ini lebih banyak mengupas tentang penjabaran makna pencemaran nama baik yang dalam Kitab Undang-Undang Hukum Pidana (KUHP) menggunakan istilah "penghinaan". Karena memang pada kenyataannya dalam hukum sendiri belum ada definisi yang tepat mengenai pengertian pencemaran nama baik. Sedangkan secara harfiah dalam Bahasa Indonesia, Wawan Tunggul Alam menuliskan bahwa pencemaran nama baik dapat diartikan sebagai perbuatan yang menodai atau mengotori nama baik seseorang. Sebagai perbandingan, buku Pencemaran Nama Baik di Kehidupan Nyata dan Dunia Internet juga memberikan definisi khusus menurut frasa Bahasa Inggris yang diartikan sebagai defamation (pencemaran nama baik), slander, libel. Slander adalah fitnah secara lisan, sedangkan libel adalah fitnah secara tertulis.

Pada bagian selanjutnya, Wawan sekaligus juga memberikan contoh-contoh kasus pencemaran nama baik yang terjadi dalam kehidupan masyarakat khususnya yang dilakukan melalui dunia internet. Seperti misalnya yang menimpa Prita Mulyasari, seorang karyawati perusahaan swasta dari Tangerang dijerat dengan UU ITE dan KUHP karena email pribadinya. Di dalam surat elektronik tersebut, Prita menyampaikan keluhannya atas layanan Rumah Sakit (RS) Omni Internasional yang berjudul "Penipuan Omni International Hospital Alam Sutera Tangerang". Munculnya kejadian ini berawal dari rasa kecewa Prita terhadap pelayanan pihak rumah sakit. Kemudian ia mengirimkan email yang berisi kritikan tersebut kepada beberapa temannya. Akan tetapi, tanpa disadarinya, kritikan tersebut kemudian menjadi viral di dunia maya. Mengetahui hal tersebut, RS Omni melaporkan ke Kepolisian dengan tuduhan pencemaran nama baik.

Tidak hanya gugatan pidana, pihak rumah sakit juga menggugat ibu dua anak tersebut secara perdata. Saat berkas sudah dilimpahkan ke Kejaksaan, Prita ditahan oleh Jaksa Penuntut Umum karena dijerat Pasal 310 KUHP dengan ancaman penjara di bawah lima tahun dan Pasal 27 UU ITE yang ancaman hukumannya enam tahun penjara. Ketika berada dalam bui saat pemeriksaan terhadap dirinya di Pengadilan sedang berlangsung, media massa terus memberitakan kasus ini. Tekanan dari masyarakat terhadap Jaksa akhirnya membuat Prita bebas untuk sementara. Hakim yang memeriksa perkara ini di Pengadilan menyatakan bahwa dakwaan Jaksa tidak dapat diterima. Pada akhirnya, Prita Mulyasari benarbenar bebas dari segala tuntutan hukum.

Belajar dari buku yang ditulis oleh Wawan Tunggul Alam dan juga kasus Prita Mulyasari ini perlu ditekankan kepada pembaca bahwa setidaknya terdapat tiga catatan yang berkaitan dengan delik pencemaran nama baik. Pertama, delik tindak pidana ini bersifat subyektif bahwa artinya untuk menentukan apakah seseorang telah melakukan pencemaran nama baik sangat bergantung pada pihak yang diserang nama baiknya. Oleh sebab itu, pencemaran nama baik termasuk dalam delik aduan di mana hanya dapat diproses secara hukum jika ada pengaduan dari pihak yang merasa nama baiknya dicemarkan. Kedua, pencemaran nama baik ialah delik penyebaran yang berarti materi dari pencemaran itu disebarluaskan kepada umum oleh pelaku. Ketiga, Delik orang yang melakukan tindakan pencemaran nama baik dengan menuduhkan sesuatu hal kepada pihak tertentu harus diberi kesempatan untuk membuktikan tuduhannya.

Buku ini juga mengkritisi sikap penegak hukum yang sampai saat ini terkesan mengutamakan selera untuk kepentingan politik maupun ekonomi dalam menerapkan pasalpasal pencemaran nama baik yang termuat dalam KUHP dan UU ITE, padahal sejatinya pemberlakuan hukum positif tidak boleh tebang pilih. Adanya sikap yang semacam ini pada akhirnya membuat rezim Republik Indonesia seakan-akan kembali pada masa orde baru yang sangat mendiskriminasi hakhak kebebasan berpendapat di muka umum. Dikuawatirkan, sikap aparat penegak hukum yang seperti itu justru membuat masyarakat semakin takut untuk menyampaikan kritikan maupun masukan kepada pihak lain, khusus- 
nya pemerintah yang sedang berkuasa. Padahal dalam sebuah sistem ketatanegaraan yang baik sangat diperlukan adanya check and balances agar pemerintah tidak keluar dari jalur dalam mengelola negara ini.

Berdasarkan kekuatiran itu, Ketua Komisi Nasional Hak Asasi Manusia (Komnas HAM) yang menjabat pada masa itu, maka Ifdhal Kasim mengusulkan agar sanksi pidana bagi pelaku pencemaran nama baik dan menyerang kehormatan orang lain dihapus saja dan mengusulkan agar persoalan ini lebih baik diselesaikan dengan jalur hukum perdata saja. Ia beralasan bahwa kehormatan dan nama baik seseorang adalah ranah privasi yang tetap berhubungan dengan hak orang lain untuk menyatakan pendapat dan berekspresi.

Di tengah bergulirnya silang pendapat terkait perlu atau tidaknya pencemaran nama baik diberikan sanksi pidana atau hanya cukup berada pada ranah perdata, saya berpendapat bahwa harus tetap ada aturan pidana dan perdata secara khusus yang mengatur tentang tindakan hukum ini. Alasannya agar dalam mengambil suatu sikap untuk berpendapat dan menyampaikan kritikan terhadap siapapun, masyarakat memiliki batasanbatasan norma hukum, etika, dan kesopanan yang tidak boleh ditabrak. Apalagi, dewasa ini sudah semakin marak berita-berita bohong yang sedemikian mudahnya tersebar hingga terkadang menimbulkan kepanikan tersendiri bagi seantero negeri.
Khusus untuk pencemaran nama baik yang dilakukan tanpa media elektronik maupun internet, maka dapat diselesaikan melalui hukum privat atau dalam hal ini perdata. Kemudian jika ditemukan kasus pencemaran nama baik yang dilakukan dengan media elektronik atau internet, maka sanksi pidana yang diberikan dapat dengan memberlakukan ketentuan yang terdapat dalam UndangUndang Informasi dan Transaksi Elektronik atau UU ITE. Regulasi yang ada dalam UU ITE menurut saya layak untuk dipertahankan mengingat kondisi saat ini yang sudah terintegrasi secara langsung dengan dunia digital dan internet. Jangan sampai suatu tindak pidana yang merugikan orang lain gagal diberlakukan gara-gara tidak ada hukum yang mengaturnya. Buku berjudul Pencemaran Nama Baik di Kehidupan Nyata dan Dunia Internet ini menarik untuk dibaca karena memiliki muatan pengetahuan terkait contoh-contoh kasus pencemaran nama baik yang pernah terjadi di Indonesia. Selain itu, Wawan Tunggul Alam selaku penulis juga tidak lupa memberikan edukasi kepada pembaca tentang bagaimana alur penyelesaian yang harus dilakukan apabila dalam kehidupan bermasyarakat ditemukan kasus pencemaran nama baik. Oleh karena itu, dalam kata pengantar sang penulis menyampaikan bahwa buku ini tidak hanya ditujukan bagi "orang-orang hukum" saja, tetapi kalangan masyarakat lainnya yang tertarik dengan berbagai macam kasus pencemaran nama baik. 